\title{
Clinical next generation sequencing of pediatric-type malignancies in adult patients identifies novel somatic aberrations
}

\author{
Jorge Galvez Silva ${ }^{1}$, Fernando F. Corrales-Medina ${ }^{2}$, Ossama M. Maher ${ }^{1,5}$, Nizar \\ Tannir $^{3}$, Winston W. Huh ${ }^{1}$, Michael E. Rytting ${ }^{1}$ and Vivek Subbiah ${ }^{1,4}$ \\ ${ }^{1}$ Division of Pediatrics, The University of Texas MD Anderson Children's Cancer Hospital, Houston, TX \\ 2 Division of Pediatric Hematology-Oncology, Department of Pediatrics, University of Miami-Miller School of Medicine, Miami, \\ FL \\ ${ }^{3}$ Department of Genitourinary Medical Oncology, Division of Cancer Medicine, The University of Texas MD Anderson Cancer \\ Center, Houston, TX \\ ${ }^{4}$ Department of Investigational Cancer Therapeutics, Division of Cancer Medicine, The University of Texas MD Anderson \\ Cancer Center, Houston, TX
}

Correspondence to: Vivek Subbiah, email: vsubbiah@mdanderson.org

Keywords: Next generation sequencing, Somatic Mutation, Solid Tumors

Received: January 30, $2015 \quad$ Accepted: February 18, $2015 \quad$ Published: February 20, 2015

This is an open-access article distributed under the terms of the Creative Commons Attribution License, which permits unrestricted use, distribution, and reproduction in any medium, provided the original author and source are credited.

\section{ABSTRACT}

Pediatric malignancies in adults, in contrast to the same diseases in children are clinically more aggressive, resistant to chemotherapeutics, and carry a higher risk of relapse. Molecular profiling of tumor sample using next generation sequencing (NGS) has recently become clinically available. We report the results of targeted exome sequencing of six adult patients with pediatric-type malignancies: Wilms tumor $(n=2)$, medulloblastoma $(n=2)$, Ewing's sarcoma( $n=1)$ and desmoplastic small round cell tumor $(n=1)$ with a median age of $\mathbf{2 8 . 8}$ years. Detection of druggable somatic aberrations in tumors is feasible. However, identification of actionable target therapies in these rare adult patients with pediatric-type malignancies is challenging. Continuous efforts to establish a rare disease registry are warranted.

\section{INTRODUCTION}

Pediatric oncologic diseases such as Ewing sarcoma (ES), Wilms tumor (WT), and medulloblastoma are infrequently found in adults. Pediatric malignancies in adults have proven to be more aggressive, resistant to chemotherapeutics, and to have a higher risk of relapse. Thus, they are very challenging to manage $[1,2]$. NGS is an appealing available test that identifies oncogenic mutations, providing some insights in cancer biology and in some cases possible actionable targeted therapies.

We conducted a retrospective chart review of adult patients who were diagnosed as having pediatrictype malignancies and were referred to the Center for Targeted Therapy and/or the Division of Pediatrics at The University of Texas MD Anderson Cancer Center. Archived tumor samples with confirmed pathology were analyzed with use of Clinical Laboratory Improvement Amendments-Next-generation sequencing at Foundation
Medicine, Cambridge, MA, USA.

\section{RESULTS}

NGS profiling for six patients was available for review (Table 1). Median age at presentation was 28.8 years (23-38 years). Four of the six patients were male. The malignancies in all patients were solid tumors. Of the six analyzed samples, five were from the primary site; only one tumor was from a metastatic site in the liver of a patient with medulloblastoma. Pathology was confirmed via morphology and support with RT-PCR and immunohistochemistry for all of the samples. All patients were treated with chemotherapy and radiotherapy prior to tumor NGS analysis. No germline DNA sequence was available.

One patient with ES harbored $C D K N 2 A / B$ gene loss and BCL2L2 and c17orf39 gene amplifications. Of the two cases with WT, one showed CTNNB1-T257I 
Table 1: Tumor Type Associated with Somatic Genetic Mutations

\begin{tabular}{|c|c|c|c|c|c|}
\hline Diagnosis & Age & Tissue sample & Radiation & $\begin{array}{c}\text { Initial } \\
\text { chemotherapy }\end{array}$ & Genomic alteration \\
\hline 1. Bone Ewing sarcoma & 23 & Primary tumor & Yes & VDI & $\begin{array}{l}C D K A 2 A / B \text { loss, } B C L 2 L 2 \text { amplifica- } \\
\text { tion, c17orf39 amplification }\end{array}$ \\
\hline 2. Kidney Wilms tumor & 36 & Primary tumor & Yes & DD4A & $\begin{array}{l}\text { CTNNB1-T257I, } \quad I G F 1 R-\mathrm{R} 595 \mathrm{H}, \\
\text { FAM123B-R353*, SPEN-Q1122 }\end{array}$ \\
\hline 3. Kidney Wilms tumor & 38 & Primary tumor & Yes & DD4A & WT1 mutation \\
\hline 4. Brain medulloblastoma & 23 & Metastasis/liver & Yes & $\begin{array}{c}\text { Vincristine, } \\
\text { carboplatin, } \\
\text { TMZ }\end{array}$ & $B R C A$-splice site $4987-1 \mathrm{G}>\mathrm{A}$ \\
\hline 5. Brain medulloblastoma & 29 & Primary tumor & Yes & $\begin{array}{c}\text { Vincristine, } \\
\text { CNNU, } \\
\text { cisplatin }\end{array}$ & PTCH-1/N97fs*43 and K163fs*6 \\
\hline 6. Soft tissue DSRCT & 25 & Primary tumor & Yes & VDC & $\begin{array}{l}A U R K B \text { amplification, } M C L 1 \\
\text { amplification (BCL2 family) }\end{array}$ \\
\hline
\end{tabular}

DD4A- vincristine, doxorubicin, dactinomycin; CNNU- lomustine; VDC- vincristine, doxorubicin, cyclophosphamide; VDI- vincristine, doxorubicin, ifosfamide; TMZ- temozolomide.

which is located in the $3^{\text {rd }}$ armadillo repeat of beta-catenin gene, IGF1R-R $595 \mathrm{H}$ which is a missense mutation in the alpha chain of the receptor, and FAM123B-R353* with $S P E N-\mathrm{Q} 1122^{*}$ that has never been reported before in genome data bases. The second patient harbored the WT1 gene mutation. The genetic aberrations in the two patients with a history of medulloblastoma were one patient with $B R C A 1$-splice site 4987-1 G>A, which corresponds to the splice acceptor site near to $\mathrm{C}$-terminus and a second patient with two different alterations in the $\mathrm{PTCH}-1$ gene, N97fs*43 and K163fs*6. One patient with desmoplastic small round cell tumor (DSRCT) harbored the novel $A U R K B$ and $M C L 1$ gene amplifications.

Clinical trials and possible off label FDA-approved drugs for the entire potential proposed target therapies were researched (Table 2). For patients with ES with $C D K N 2 A / B$ gene alterations possible targets for the molecules CDK4 and CDK6 were found, but no targets are available for gene loss of function. No possible targets were found for the BCL2L2 or c17orf39 amplifications. For the patient with WT who harbored CTNNB1 no therapies were found. $I G F 1 R$, possible targets include small molecules inhibitors in early clinical studies[3-5], whereas for the patient with WT-1 mutation, WT-1 pathway peptides are still under basic research and early clinical studies[6]. In the case of the medulloblastoma, BRCA1 mutations may be targeted with DNA damaging drugs such as platinum and PARP inhibitors that are currently in clinical trials for brain tumors[7-9]; furthermore, the PTCH-1 aberration seen in medulloblastoma could be targeted with $\mathrm{SMO} / \mathrm{SHH}$ inhibitors such as vismodegib[10]. The DSRCT tumor harbored the $A U R K B$ and MCL1 gene amplifications with no approved therapies, nonetheless, there are few clinical trials targeting Aurora kinases and CDK inhibitors[11-13].

\section{DISCUSSION}

The recent advances in genomics have proved to be linked to prognosis and response to therapy, for instance BRAF inhibitors have changed the landscape of $B R A F$ V600 E mutant melanomas[14, 15], and ALK inhibitors have dramatically changed the outcome of EML4-ALK mutant lung cancer patients[16]. NGS is a novel available technology that can provide valuable information leading to more accurate diagnosis, improved classification, and new biologic-based treatments. NGS could help in elucidating if the genetics of pediatric tumors may differ from that of adult tumors, even if the tumors for both groups are categorized as the same entities. This can be explained because many pediatric malignancies, when found in adult patients, may carry novel and/or more complex somatic mutations. For example, our patient with ES harbored $C D K A 2 A / B$ loss, BCL2L2 and c17orf39 amplifications, with the latter amplifications never having been reported previously in patients with ES[17].

$C D K N 2 A / B$ loss has appeared as an emergent mutation in ES that can be seen in 5\%-12\% of primary tumors and in up to $33 \%-50 \%$ of cell lines[18, 19]. Although Brownhill et al. did not show prognostic relevance in homozygous loss or single deletion of $C D K N 2 A$, other studies of aggressive sarcomas have shown an association between genomic alterations and disease progression $[1,2,20]$. In a pre-clinical model 
TABLE II: Potential Target Therapies

\begin{tabular}{|c|c|c|c|}
\hline Disease & Gene affected & Possible Targets Pathways & Possible therapies \\
\hline Bone Ewing Sarcoma & $\begin{array}{l}\text { CDKA2A/B mutation/loss } \\
\text { BCL2L2 and c17orf39 } \\
\text { amplification }\end{array}$ & $\begin{array}{l}\text { CDK4, CDK6 } \\
\text { Bcl-w }\end{array}$ & $\begin{array}{l}\text { CDK4/6 inhibitors \#* } \\
\text { Navitoclax* }\end{array}$ \\
\hline Wilms Tumor & $\begin{array}{c}\text { CTNNB1 } \\
\text { IGF1R, } \\
\text { FAM123B, SPEN Q1122 }\end{array}$ & $\begin{array}{l}\text { Beta-catenin, Wnt } \\
\text { IGFR, EGF1R, MTOR } \\
\text { No targets }\end{array}$ & $\begin{array}{c}\text { PRI-724*, OMP-54F28*, AMG 479*, } \\
\text { Everolimus, } \\
\begin{array}{c}\text { Temsirolimus, } \\
\text { Panitumumab }\end{array}\end{array}$ \\
\hline Wilms Tumor & WT1 Mutations & WT1 & $\begin{array}{l}\text { WT1-peptide-based immunotherapy, HLA- } \\
\text { A*2404-restricted, 9-mer WT1 peptide }\end{array}$ \\
\hline Medulloblastoma & BRCA & PARP & PARP inhibitors (rucaparib)* \\
\hline Medulloblastoma & PTCH-1 & $\mathrm{SMO}(\mathrm{SHH})$ & Vismodegib (GDC-0449) \\
\hline $\begin{array}{l}\text { Desmoplastic small } \\
\text { round cell tumor }\end{array}$ & $\begin{array}{c}\text { AURKB } \\
\text { MCL1 } \\
* * \text { ARID1A, }{ }^{* * R U N X 1}\end{array}$ & $\begin{array}{l}\text { Aurora kinase (chromosomal } \\
\text { passenger complex) } \\
\text { CSF1R, FLT3 } \\
\text { PDGFRB, VEGFR-1-3; } \\
\text { CDK1-4, 7, } 9 .\end{array}$ & $\begin{array}{l}\text { AMG } 900 * \text { ASLAN002* } \\
\text { Sorafenib, } \\
\text { BAY 1000394* }\end{array}$ \\
\hline
\end{tabular}

*No US Federal Drug Administration (FDA) approval. **Variance of unknown significance detected in the tumor sample. ${ }^{\#}$ Unknown value in loss of function mutations.

loss of CDKN2A expression correlated with sensitivity to CDK4/6 inhibitors[21]. However, clinical data is lacking[21].

$B C L 2 L 2$ amplification has never been found in ES. However, it has been associated with lower longterm survival in osteosarcoma [22]. C17orf39 (GID4) amplification seen in our patient is another novel mutation for ES. This genomic event lies in the chromosome 17p11 frequently amplified in osteosarcoma and occasionally in gliomas [23, 24]. Currently, there are no targeted therapies available to address these aforementioned amplifications.

Our patient with WT harbored four alterations: CTNNB1-T257I, IGF1R-R595H, FAM123B-R353*, and $S P E N-\mathrm{Q} 1122 *$. CTNNB1 encodes for a protein named, beta-catenin, found in $15 \%-19 \%$ of patients with WT [25]. Some mutations in this gene such as T41A have been associated with significantly lower survival and resistance to chemotherapy in WT, however the biology effect in T257I is unknown [26].

$I G F 1 R-\mathrm{R} 595 \mathrm{H}$ is a missense mutation in which the effect of the protein alteration is unknown. It has never been associated with WT. However, amplification of the tyrosine kinase has been observed in $10 \%$ of WT and has been associated with poor prognosis and relapse [27].

Somatic mutations in FAM123 is rare in cancers genome databases, nonetheless is observed in $5-30 \%$ WT[28-30]. Overexpression of SPEN-Polyvalent transcriptional co-repressor have been suggested as an enhancer of the Wnt pathway, which has been also reported in colon and ovarian cancers.[28, 29, 31, 32] Currently, no targeted therapies are available.

Our patient with medulloblastoma was found to have $B R C A 1$-splice site $4987-1-\mathrm{G}>\mathrm{A}$ that may lead to production of a truncated protein that prevents the $B R C T$ domain from binding to several tumor suppressor proteins [33]. The BRCA mutation may be sensitive to DNAdamaging drugs such as platinum and PARP inhibitors [7]. Our second patient with medulloblastoma showed the PTCH-1- N97fs*43 and K163fs*6 mutations. Mutations in this gene have been found in $15 \%$ of medulloblastoma in genome databases. PTCH encodes for the Ptcl protein, a component of the hedgehog pathway. This pathway has been targeted with small molecules such as vismodegib, an inhibitor of the smoothened protein and a member of the hedgehog-signaling pathway. Rudin at el. reported tumor regression in 2009 after 3 months of therapy in patients with medulloblastoma [10].

Finally, our patient with DSRCT showed amplification in $A U R K B$ and $M C L 1$ genes. AURKB had never been associated with DSRCT. Decreased aurora kinase protein expression has been linked with poor response to chemotherapy in ovarian cancer [34].

MCL1 encodes for the protein $\mathrm{Mcl}-1$, which is a member of the $B c l-2$ family. Amplification has been found in up to $10 \%$ of all tumors studied. It is more frequently found in aggressive tumors such as breast cancer and lung cancer [35].

NGS technology has helped identify additional 
genomics, epigenetics, and molecular aberrations that need more profound studies and analyses. Studies have shown that some alterations can be linked to prognosis in many tumors. Our understanding of the aggressive characteristics of pediatric malignancies in adults still has many gaps. This represents a challenge for physicians who seek to develop more individualized treatment strategies, as well as potential targets and clinical trials that will prove the safety and efficacy. Also, it would be of interest to analyze tumor samples pre-treatment as well as DNA germline sequence for each of the patients.

\section{CONCLUSION}

Identification of somatic aberrations in adult patients with pediatric-type malignancies with use of CLIAcertified clinical NGS is feasible. Moreover, finding targeted therapies is complicated. Establishing a rare disease registry is warranted. In addition, further larger analyses of these types of patients such as The Cancer Genome Atlas along with clinical correlation are needed.

\section{PATIENTS AND METHODS}

A retrospective electronic medical record review of adult patients with advanced metastatic pediatric-type malignancies was conducted. These charts were derived from patients who were referred to the Department of Investigational Cancer Therapeutics (Phase I Clinical Trials Program) and/ or Division of Pediatrics. Tissue samples were based on archival samples from primary malignancy specimen or a biopsy from metastatic site. The University of Texas MD Anderson Cancer Center Institutional Review Board approval was obtained. All patients provided written informed consent for participation and for the chemotherapy or targeted therapy they received.

\section{Specimen analysis}

Clinical targeted next-generation sequencing (NGS) analysis were performed by Foundation Medicine (Boston, MA) to identify genomic alterations within targeted 186 cancer-related genes.

\section{Statistical analysis}

There is no formal hypothesis testing in this retrospective study. This is mainly a descriptive case series and we used descriptive statistics to report the findings.

\section{CONFLICT OF INTEREST}

All Authors have seen and approved the manuscript and have no conflict of interest to declare.

\section{Grant sponsor}

Supported by the NIH/NCI under award number P30CA016672 Presented in part at the American Society of Pediatric Hematology/Oncology meeting (ASPHO) April 2014, Chicago, IL

\section{REFERENCES}

1. Honoki K, Stojanovski E, McEvoy M, Fujii H, Tsujiuchi T, Kido A, Takakura Y and Attia J. Prognostic significance of p16 INK4a alteration for Ewing sarcoma: a meta-analysis. Cancer. 2007; 110(6):1351-1360.

2. Mohseny AB, Tieken C, van der Velden PA, Szuhai K, de Andrea C, Hogendoorn PC and Cleton-Jansen AM. Small deletions but not methylation underlie CDKN2A/p16 loss of expression in conventional osteosarcoma. Genes, chromosomes \& cancer. 2010; 49(12):1095-1103.

3. Arnaldez FI and Helman LJ. Targeting the insulin growth factor receptor 1. Hematol Oncol Clin North Am. 2012; 26(3):527-542, vii-viii.

4. Subbiah V and Kurzrock R. Phase 1 clinical trials for sarcomas: the cutting edge. Curr Opin Oncol. 2011; 23(4):352-360.

5. Adachi Y, Yamamoto H, Ohashi H, Endo T, Carbone DP, Imai $\mathrm{K}$ and Shinomura Y. A candidate targeting molecule of insulin-like growth factor-I receptor for gastrointestinal cancers. World J Gastroenterol. 2010; 16(46):5779-5789.

6. Ohno S, Okuyama R, Aruga A, Sugiyama H and Yamamoto M. Phase I trial of Wilms' Tumor 1 (WT1) peptide vaccine with GM-CSF or CpG in patients with solid malignancy. Anticancer research. 2012; 32(6):2263-2269.

7. Leung M, Rosen D, Fields S, Cesano A and Budman DR. Poly(ADP-ribose) polymerase-1 inhibition: preclinical and clinical development of synthetic lethality. Molecular medicine. 2011; 17(7-8):854-862.

8. Fong PC, Yap TA, Boss DS, Carden CP, Mergui-Roelvink M, Gourley C, De Greve J, Lubinski J, Shanley S, Messiou C, A'Hern R, Tutt A, Ashworth A, Stone J, Carmichael J, Schellens JH, et al. Poly(ADP)-ribose polymerase inhibition: frequent durable responses in BRCA carrier ovarian cancer correlating with platinum-free interval. Journal of clinical oncology : official journal of the American Society of Clinical Oncology. 2010; 28(15):25122519.

9. Chalmers AJ. The potential role and application of PARP inhibitors in cancer treatment. British medical bulletin. 2009; 89:23-40. 
10. Rudin CM, Hann CL, Laterra J, Yauch RL, Callahan CA, Fu L, Holcomb T, Stinson J, Gould SE, Coleman B, LoRusso PM, Von Hoff DD, de Sauvage FJ and Low JA. Treatment of medulloblastoma with hedgehog pathway inhibitor GDC-0449. The New England journal of medicine. 2009; 361(12):1173-1178.

11. Bettayeb K, Baunbaek D, Delehouze C, Loaec N, Hole AJ, Baumli S, Endicott JA, Douc-Rasy S, Benard J, Oumata N, Galons H and Meijer L. CDK Inhibitors Roscovitine and CR8 Trigger Mcl-1 Down-Regulation and Apoptotic Cell Death in Neuroblastoma Cells. Genes \& cancer. 2010; 1(4):369-380.

12. Walsby E, Lazenby M, Pepper C and Burnett AK. The cyclin-dependent kinase inhibitor SNS-032 has single agent activity in AML cells and is highly synergistic with cytarabine. Leukemia. 2011; 25(3):411-419.

13. Kollareddy M, Zheleva D, Dzubak P, Brahmkshatriya PS, Lepsik M and Hajduch M. Aurora kinase inhibitors: progress towards the clinic. Investigational new drugs. 2012; 30(6):2411-2432.

14. Flaherty KT, Puzanov I, Kim KB, Ribas A, McArthur GA, Sosman JA, O'Dwyer PJ, Lee RJ, Grippo JF, Nolop K and Chapman PB. Inhibition of mutated, activated BRAF in metastatic melanoma. The New England journal of medicine. 2010; 363(9):809-819.

15. Arkenau HT, Kefford R and Long GV. Targeting BRAF for patients with melanoma. British journal of cancer. 2011; 104(3):392-398.

16. Kwak EL, Bang YJ, Camidge DR, Shaw AT, Solomon B, Maki RG, Ou SH, Dezube BJ, Janne PA, Costa DB, Varella-Garcia M, Kim WH, Lynch TJ, Fidias P, Stubbs H, Engelman JA, et al. Anaplastic lymphoma kinase inhibition in non-small-cell lung cancer. The New England journal of medicine. 2010; 363(18):1693-1703.

17. Jiang Y, Subbiah V, Janku F, Ludwig JA, Naing A, Benjamin RS, Brown RE, Anderson P and Kurzrock R. Novel Secondary Somatic Mutations in Ewing's Sarcoma and Desmoplastic Small Round Cell Tumors. PloS one. 2014; 9(8):e93676.

18. Brohl AS, Solomon DA, Chang W, Wang J, Song Y, Sindiri S, Patidar R, Hurd L, Chen L, Shern JF, Liao H, Wen X, Gerard J, Kim JS, Lopez Guerrero JA, Machado I, et al. The genomic landscape of the Ewing Sarcoma family of tumors reveals recurrent STAG2 mutation. PLoS genetics. 2014; 10(7):e1004475.

19. Tirode F, Surdez D, Ma X, Parker M, Le Deley MC, Bahrami A, Zhang Z, Lapouble E, Grossetete-Lalami S, Rusch M, Reynaud S, Rio-Frio T, Hedlund E, Wu G, Chen X, Pierron G, et al. Genomic Landscape of Ewing Sarcoma Defines an Aggressive Subtype with Co-Association of STAG2 and TP53 Mutations. Cancer discovery. 2014.

20. Brownhill SC, Taylor C and Burchill SA. Chromosome 9p21 gene copy number and prognostic significance of p16 in ESFT. British journal of cancer. 2007; 96(12):1914-1923.
21. Young RJ, Waldeck K, Martin C, Foo JH, Cameron DP, Kirby L, Do H, Mitchell C, Cullinane C, Liu W, Fox SB, Dutton-Regester K, Hayward NK, Jene N, Dobrovic A, Pearson RB, et al. Loss of CDKN2A expression is a frequent event in primary invasive melanoma and correlates with sensitivity to the CDK4/6 inhibitor PD0332991 in melanoma cell lines. Pigment cell \& melanoma research. 2014; 27(4):590-600.

22. Wu X, Cai ZD, Lou LM and Zhu YB. Expressions of p53, c-MYC, BCL-2 and apoptotic index in human osteosarcoma and their correlations with prognosis of patients. Cancer epidemiology. 2012; 36(2):212-216.

23. van Dartel M, Leenstra S, Troost D and Hulsebos TJ. Infrequent but high-level amplification of $17 \mathrm{p} 11.2$ approximately p12 in human glioma. Cancer genetics and cytogenetics. 2003; 140(2):162-166.

24. van Dartel M, Redeker S, Bras J, Kool M and Hulsebos TJ. Overexpression through amplification of genes in chromosome region 17 p11.2 approximately p12 in highgrade osteosarcoma. Cancer genetics and cytogenetics. 2004; 152(1):8-14.

25. Kikuchi A. Regulation of beta-catenin signaling in the Wnt pathway. Biochemical and biophysical research communications. 2000; 268(2):243-248.

26. Cardoso LC, De Souza KR, De ORAH, Andrade RC, Britto AC, Jr., De Lima MA, Dos Santos AC, De Faria PS, Ferman $\mathrm{S}$, Seuanez HN and Vargas FR. WT1, WTX and CTNNB1 mutation analysis in 43 patients with sporadic Wilms' tumor. Oncology reports. 2013; 29(1):315-320.

27. Natrajan R, Reis-Filho JS, Little SE, Messahel B, Brundler MA, Dome JS, Grundy PE, Vujanic GM, Pritchard-Jones $\mathrm{K}$ and Jones C. Blastemal expression of type I insulinlike growth factor receptor in Wilms' tumors is driven by increased copy number and correlates with relapse. Cancer research. 2006; 66(23):11148-11155.

28. Perotti D, Gamba B, Sardella M, Spreafico F, Terenziani M, Collini P, Pession A, Nantron M, Fossati-Bellani F and Radice P. Functional inactivation of the WTX gene is not a frequent event in Wilms' tumors. Oncogene. 2008; 27(33):4625-4632.

29. Ruteshouser EC, Robinson SM and Huff V. Wilms tumor genetics: mutations in WT1, WTX, and CTNNB1 account for only about one-third of tumors. Genes, chromosomes \& cancer. 2008; 47(6):461-470.

30. Rivera MN, Kim WJ, Wells J, Driscoll DR, Brannigan BW, Han M, Kim JC, Feinberg AP, Gerald WL, Vargas SO, Chin L, Iafrate AJ, Bell DW and Haber DA. An X chromosome gene, WTX, is commonly inactivated in Wilms tumor. Science. 2007; 315(5812):642-645.

31. Feng Y, Bommer GT, Zhai Y, Akyol A, Hinoi T, Winer I, Lin HV, Cadigan KM, Cho KR and Fearon ER. Drosophila split ends homologue SHARP functions as a positive regulator of Wnt/beta-catenin/T-cell factor signaling in neoplastic transformation. Cancer research. 2007; 67(2):482-491. 
32. Major MB, Camp ND, Berndt JD, Yi X, Goldenberg SJ, Hubbert C, Biechele TL, Gingras AC, Zheng N, Maccoss MJ, Angers S and Moon RT. Wilms tumor suppressor WTX negatively regulates $\mathrm{WNT} /$ beta-catenin signaling. Science. 2007; 316(5827):1043-1046.

33. Ludwig T, Fisher $\mathrm{P}$, Ganesan $\mathrm{S}$ and Efstratiadis A. Tumorigenesis in mice carrying a truncating Brcal mutation. Genes \& development. 2001; 15(10):1188-1193.

34. Hetland TE, Nymoen DA, Holth A, Brusegard K, Florenes VA, Kaern J, Trope CG and Davidson B. Aurora $\mathrm{B}$ expression in metastatic effusions from advancedstage ovarian serous carcinoma is predictive of intrinsic chemotherapy resistance. Human pathology. 2013; 44(5):777-785.

35. Beroukhim R, Mermel CH, Porter D, Wei G, Raychaudhuri S, Donovan J, Barretina J, Boehm JS, Dobson J, Urashima M, Mc Henry KT, Pinchback RM, Ligon AH, Cho YJ, Haery L, Greulich H, et al. The landscape of somatic copynumber alteration across human cancers. Nature. 2010; 463(7283):899-905. 